\title{
Miocene high-temperature magmatism in the Himalayan orogen
}

PENG GAO ${ }^{1}$, YONG-Fei ZHENG ${ }^{1}$, MATTHEW JASON MAYNE $^{2}$, ZHI-CHAO LIU ${ }^{3}$, ZI-FU ZHAO ${ }^{1}$

${ }^{1}$ CAS Key Laboratory of Crust-Mantle Materials and Environments, School of Earth and Space Sciences, University of Science and Technology of China, Hefei 230026, China

${ }^{2}$ Department of Earth Sciences, University of Stellenbosch, Matieland 7602, South Africa

${ }^{3}$ School of Earth Science and Geological Engineering, Sun Yat-sen University, Guangzhou 510275, China

Himalayan leucogranites are generally thought to be produced by partial melting of metasedimentary rocks at relatively low temperatures of $<800{ }^{\circ} \mathrm{C}$. Whether Cenozoic high-temperature $\left(>800^{\circ} \mathrm{C}\right)$ granites have been formed in the Himalayan orogen is poorly known. Here we used Ti-inzircon thermometer combined with thermodynamically

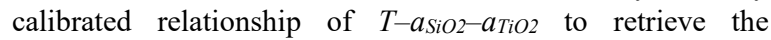
crystallization temperature of the ca. 17 Ma two-mica granites from Yalaxiangbo. The maximum value of crystallization temperature (ca. $850{ }^{\circ} \mathrm{C}$ ) provides a significant constraint on the partial melting temperature of the sources, which were suggested to be Na-rich metasedimentary rocks based on the $\mathrm{Sr}-\mathrm{Nd}$ isotopic compositions and zircon $\mathrm{U}-\mathrm{Pb}$ age spectrum. Furthermore, phase equilibrium modeling using the Na-rich metasedimentary rocks as the sources indicates that partial melts produced at $\mathrm{T}=850{ }^{\circ} \mathrm{C}$ and $\mathrm{P}=6-10 \mathrm{kbar}$ can best match the target granites in major element compositions. Our results demonstrate that melting temperatures for the formation of Himalayan leucogranites probably have been underestimated in previous studies. Such high temperatures are difficult to be accounted for by radiogenic and frictional heating of the crust alone, but require an extra heat source, probably provided by the upwelling asthenosphere beneath the south Tibet.

Keywords: Himalaya; Leucogranites; High-temperature; Phase equilibrium modeling 